\title{
INFLUENCE OF FATIGUE IMPACT LOADING ON RADIAL CARRIER AND RAPPING DEVICE FILLET WELD STRENGTH
}

\author{
Josip Sertić, Ivan Samardžić, Dražan Kozak, Damir Šimunić, Ivan Gelo, Dino Bučević-Keran
}

Professional paper

The device used to shake off the ash of the steam boiler harp consists of a drive shaft which has radial carriers welded on. During the operation of the waste incinerator steam boiler in Riverside, a fracture of the radial carrier and drive shaft weld occurred. Such a welded T-joint is made as a double fillet weld. It is loaded with the impact loading which causes the fatigue of material because of its repetition. The analytical calculation, with which the loadbearing capacity of the welded joint is determined, is suggested in this paper. The suggested analytical calculation of the mean impact force is based on the law of momentum conservation during the collision of rapping device and elastically deformable heat exchanger harp. The mean impact force is applied for the weld strength calculation. The results showed that the use of double fillet weld loaded with the fatigue impact loading was a bad choice. The suggested analytical calculation model is applicable for the rapping device design.

Keywords: double fillet weld; fatigue; impact loading; rapping device; strength

Utjecaj udarnog zamornog opterećenja na čvrstoću kutnog zavarenog spoja radijalnog nosača i pogonskog vratila udarača

Stručni članak

Uređaj za stresanje pepela s izmjenjivačkih harfi parnog kotla sastoji se od pogonskog vratila na koje su zavareni radijalni nosači čekića. U radu parnog kotla spalionice smeća u Riverside-u došlo je do loma zavarenog spoja radijalnog nosača i pogonskog vratila udarača. Zavareni spoj radijalnog nosača i vratila izveden je kao obostrani kutni zavareni spoj. Ovaj zavareni spoj opterećen je udarnim opterećenjem koje zbog ponavljajućeg karaktera prouzrokuje zamor materijala. U radu je predložen analitički proračun kojim je utvrđena nosivost zavarenog spoja. Predloženi analitički proračun srednje sile sudara temelji se na zakonu očuvanja količine gibanja uslijed sudara čekića udarača i elastično deformabilne harfe izmjenjivača topline. Srednja sila sudara primjenjuje se kod proračuna čvrstoće zavarenog spoja. Dobiveni rezultati pokazali su da je primjena kutnog zavarenog spoja opterećenog udarnim zamornim opterećenjem loš izbor. Predloženi model analitičkog proračuna moguće je primijeniti kod dizajna udarača.

Ključne riječi: čvrstoća; obostrani kutni zavareni spoj; udarač; udarno opterećenje; zamor

\section{Introduction}

During the process of incineration in a waste incinerator steam boiler, smoke appears and it flows over the heat exchanger. Smoke carries the ash particles which stick to the heat exchanger surfaces, thus creating a fouling which reduces the efficiency of heat exchange. On the harp heat exchangers, the fouling is removed using a rapping device which can be mechanical or pneumatic. The rapping device strikes the head of the harp header indirectly, through the mandrel, thus transmitting the kinetic energy. This amount of kinetic energy has to be sufficient for the harp to start swinging. Due to the harp swinging, the inertial forces appear on the fouling layer, which are greater than the adhesive forces between the surface of heat exchanger pipe and the fouling layer. This leads to the detachment of fouling from the surface of heat exchanger pipe. The strength of mechanical rapping device double fillet weld will be analysed in this paper. The radial carrier, Fig. 1, is welded with a double fillet weld to a drive shaft. The radial carrier carries a rapping device hammer. Because of the mechanics of hammer movement, the radial carrier and drive shaft welded joint are exposed to the fatigue impact loading. This is the reason for the fracture of these welded joints that appeared on the rapping devices of steam boiler Riverside after the critical number of impact loading cycles. The impact loading is a very complex mechanical problem which can generally include large deformations, nonlinearity of material, elastic and plastic stability, and material properties at high deformation speed $[1,2]$. The movement physics includes the law of energy conservation and the law of momentum conservation. The energy dissipation in the contact zone is hard to predict. Therefore the law of momentum conservation is the basis for studying of collision/impact mechanics. At the moment of rapping device impact to the lower header head, the elastic deformation occurs, as well as the plastic deformation in the impact zone. According to the St. Venant principle, the local deformation effects can be excluded from the global response of the harp due to the impact loading, and examined separately. The impact mechanics of rapping device hammer and heat exchanger harp will be analysed for determining the loading of welded joint. Thereat, the elastic deformation of harp will be assumed. In the paper [3], the influence of impact loading on the heat exchanger harp strength is examined. The analytical method for determining the rapping device equivalent impact force is presented there. This analytical model of calculation is applied for strength calculation of the heat exchanger harp on Vaasa waste incinerator boiler [4].

Beside the inappropriate weld geometry, it is supposed that the fractures occurred because of the inadequate microstructure of the welded joint surface. Since the fatigue of material is a surface problem, significant fatigue strength improvements can be accomplished with the surface heat treatment [5]. Because of the frequent impacts of rapping device, this welded joint is exposed to the high-cycle fatigue. The high-cycle fatigue, due to the impact loading on the structural steels, was researched by Shul'ginov [6], who proved that with the same amplitude of dynamic loading, the amount of endurance limit of examined material is slightly higher for the impact loading than for the steady alternating (harmonic) loading. The influence of impact loading on 
the fatigue strength of steel at the room temperature was researched by Davidenkov, Belyaeva, Silkin, Tolkachnikn and Sidnev $[7 \div 10]$.

The analytical strength calculation model of the rapping device and drive shaft weld joint, which will be presented here, is developed for the needs of waste incinerator boiler project in Riverside [11], and it is the extension of earlier research $[3,4]$.

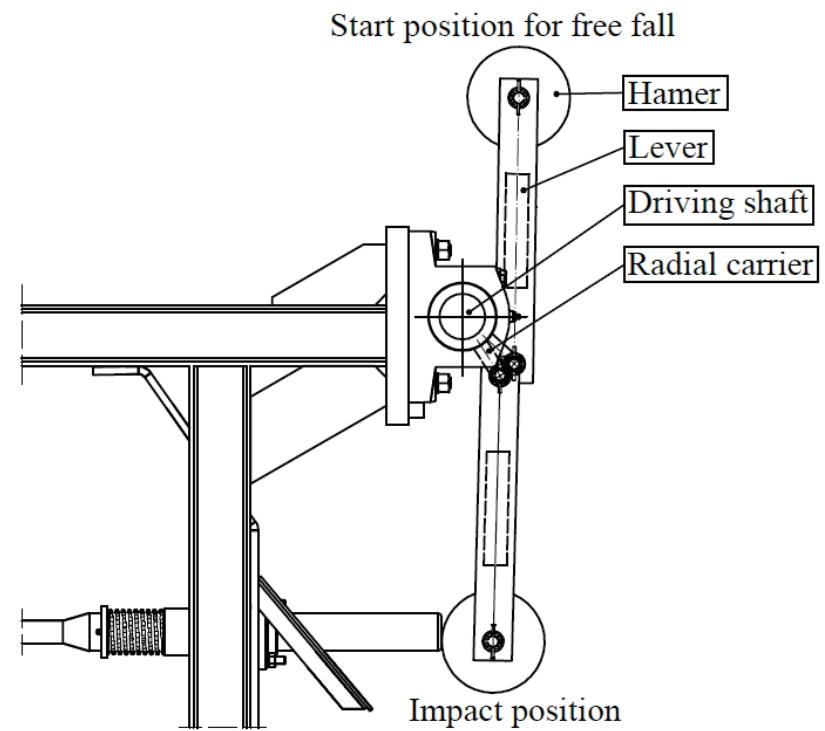

Figure 1 Basic construction elements of the mechanical rapping device important for the analysis

\section{Determining the influence of inertial forces due to the impact of rapping device in the case of an ideal response of exchanger harp}

The harp of heat exchanger represents a frame structure. The rapping device indirectly strikes over a mandrel at the batting head of lower header of exchanger harp in the direction of its longitudinal axis. With the help of the spring, it is secured that the mandrel rests the whole time on the batting head, so it can be viewed during the collision kinetics analysis as part of the harp of exchanger. This problem represents the eccentric plane collision in which the law of momentum conservation is valid. Since the harp consists of $n$ number of pipes, it is enough to consider the elastic deformation problem of only one pipe, Fig. 2.

During the impact of rapping device into the exchanger harp, the harp will receive a certain amount of the momentum. The momentum of upper chamber will be disregarded because of the small movements during deformation. During the collision of the hammer and harp, the lower chamber will gain the momentum which can be calculated with the expression

$p_{\mathrm{k}}=m_{\mathrm{k}} \cdot v_{0}(l)$

where $m_{\mathrm{k}}$ is the mass of lower chamber, and $v_{0}(l)$ is the velocity of lower chamber right after the impact of rapping device. It can be noticed that in this expression, the change of momentum due to deformation is not taken into account. Because of the small deformations, this influence can be disregarded.

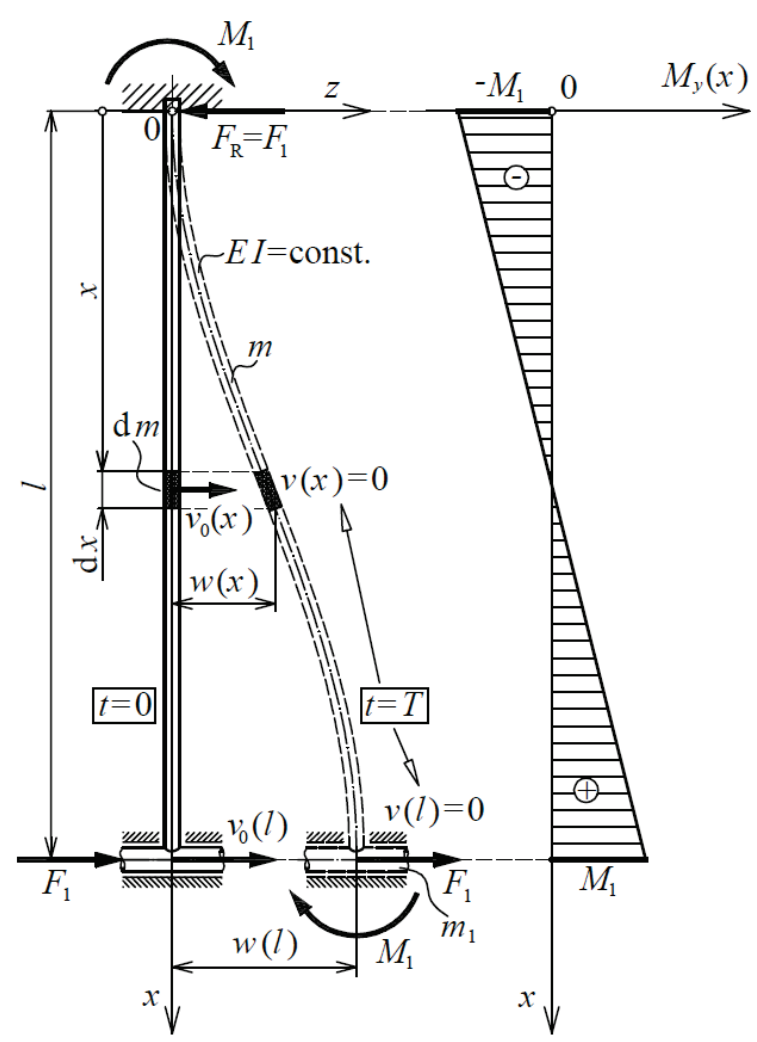

Figure 2 Mechanical model of elastic deformation of the harp exchanger pipe

The pipe momentum in harp can be calculated with the expression

$p_{\mathrm{c}}=p_{1} \cdot \mathrm{n}$,

where $p_{1}$ is the momentum of one pipe of the exchanger harp, and $\mathrm{n}$ is the number of pipes in the harp. The total momentum that the harp can take during the impact of rapping device, is equal to

$p=p_{\mathrm{k}}+p_{\mathrm{c}}$.

According to the defined boundary conditions (Fig. 2), after the impact of rapping mandrel, the harp will be deformed. The harp pipe momentum will be

$\mathrm{d} p_{1}=v_{0}(x) \mathrm{d} m_{1}$.

where

$\mathrm{d} m_{1}=\rho \mathrm{d} V_{1}=A \cdot \rho \mathrm{d} x$,

and the Eq. (4) can be written

$p_{1}=A \cdot \rho \cdot \int_{0}^{l} v_{0}(x) \mathrm{d} x$

If we assume that the equivalent force of the harp pipe deformation is constant $\left(F_{1}=\right.$ const. $\rightarrow a=$ const. $)$ after the impact of rapping mandrel, we can get the expression which connects the deflection of pipe $w(x)$ with the velocity $v_{0}(x)$. If $T$ is the time necessary for the 
pipe of harp to reach the maximum deflection, then we get

$$
\begin{aligned}
& 0=v_{0}(l)-a(l) \cdot T \rightarrow a(l)=\frac{v_{0}(l)}{T}, \\
& 0=v_{0}(x)-a(x) \cdot T \rightarrow a(x)=\frac{v_{0}(x)}{T}, \\
& w(l)=v_{0}(l) \cdot T-\frac{1}{2} \cdot a(l) \cdot T^{2}=\frac{1}{2} \cdot v_{0}(l) \cdot T, \\
& w(x)=v_{0}(x) \cdot T-\frac{1}{2} \cdot a(x) \cdot T^{2}=\frac{1}{2} \cdot v_{0}(x) \cdot T .
\end{aligned}
$$

Dividing the Eq. (9) with Eq. (10), we can get the expression

$\frac{w(l)}{w(x)}=\frac{v_{0}(l)}{v_{0}(x)}$,

and we can conclude that the maximum deflection of pipe of harp is proportional to the velocity of pipe of harp after the impact. This law needs to be fulfilled, because we are considering the linear elastic deformation of pipe of harp. The elastic line differential equation of bending of pipe of harp is

$$
\frac{\mathrm{d}^{2} w(x)}{\mathrm{d} x^{2}}=-\frac{M_{y}(x)}{E \cdot I} .
$$

The reactive moment in the welded joint of pipe and chamber (upper and lower) of the exchanger harp, according to Fig. 2, is

$$
M_{1}=\frac{1}{2} \cdot F_{1} \cdot l
$$

The law of bending moment distribution (Fig. 2) along the pipe of harp is

$$
M_{y}(x)=F_{1} \cdot x-M_{1}=F_{1} \cdot\left(x-\frac{1}{2} \cdot l\right) .
$$

By inserting the Eq.(14) in Eq. (12), we will get

$$
\frac{\mathrm{d}^{2} w(x)}{\mathrm{d} x^{2}}=\frac{F_{1}}{E \cdot I} \cdot\left(\frac{1}{2} \cdot l-x\right) .
$$

After the integration of Eq. (15), we can get

$$
\begin{aligned}
& \frac{\mathrm{d} w(x)}{\mathrm{d} x}=\frac{F_{1}}{2 \cdot E \cdot I} \cdot\left(l \cdot x-x^{2}\right)+\mathrm{C}_{1}, \\
& \frac{\mathrm{d} w(0)}{\mathrm{d} x}=0 \rightarrow \mathrm{C}_{1}=0, \\
& \frac{\mathrm{d} w(x)}{\mathrm{d} x}=\frac{F_{1}}{2 \cdot E \cdot I} \cdot\left(l \cdot x-x^{2}\right), \\
& w(x)=\frac{F_{1}}{E \cdot I} \cdot\left(\frac{1}{4} \cdot l \cdot x^{2}-\frac{1}{6} \cdot x^{3}\right)+\mathrm{C}_{2}, \\
& w(0)=0 \rightarrow \mathrm{C}_{2}=0,
\end{aligned}
$$

$$
w(x)=\frac{F_{1}}{E \cdot I} \cdot\left(\frac{1}{4} \cdot l \cdot x^{2}-\frac{1}{6} \cdot x^{3}\right) .
$$

The maximum deflection of pipe of harp, according to the Eq. (17), is

$$
w(l)=\frac{F_{1} \cdot l^{3}}{12 \cdot E \cdot I} .
$$

If we insert the Eq. (17) and Eq. (18) in Eq. (11), we get the expression for the velocity of pipe of harp immediately after the impact

$v_{0}(x)=\frac{6 \cdot v_{0}(l)}{l^{3}} \cdot\left(\frac{1}{2} \cdot l \cdot x^{2}-\frac{1}{3} \cdot x^{3}\right)$.

Now, the momentum of pipe of harp, immediately after the impact of rapping device, can be calculated with the Eqs.(6) and (19)

$$
\begin{aligned}
& p_{1}=\frac{6 \cdot A \cdot \rho \cdot v_{0}(l)}{l^{3}} \cdot \int_{0}^{l}\left(\frac{1}{2} \cdot l \cdot x^{2}-\frac{1}{3} \cdot x^{3}\right) \mathrm{d} x, \\
& p_{1}=\frac{1}{2} \cdot A \cdot \rho \cdot l \cdot v_{0}(l) .
\end{aligned}
$$

If the mass of one pipe is

$m_{1}=\rho \cdot A \cdot l$,

then the momentum of pipe of harp is

$p_{1}=\frac{1}{2} \cdot m_{1} \cdot v_{0}(l)$

With the Eqs. (1), (2), (3) and (22), we can get the momentum of exchanger harp

$p=\left(m_{\mathrm{k}}+\frac{1}{2} \cdot m_{1} \cdot \mathrm{n}\right) \cdot v_{0}(l)$

The balance of momentum for the bodies that are included in the impact can be written as

$p_{\mathrm{u}}^{(1)}=p_{\mathrm{u}}^{(2)}+p$

where $p_{\mathrm{u}}{ }^{(1)}$ is the momentum of rapping device just before the impact, and $p_{\mathrm{u}}{ }^{(2)}$ is the momentum of rapping device just after the impact. The momentum of rapping device contains the momentum of lever $p_{\mathrm{p}}$ and the momentum of hammer $p_{\mathrm{h}}$,

$$
\begin{aligned}
& p_{\mathrm{u}}^{(1)}=p_{\mathrm{p}}^{(1)}+p_{\mathrm{h}}^{(1)}, \\
& p_{\mathrm{u}}^{(2)}=p_{\mathrm{p}}^{(2)}+p_{\mathrm{h}}^{(2)}
\end{aligned}
$$

The inertial force, which occurs during the impact because of the mass of hammer, does not influence the value of reactive force in the joint of lever and radial 
carrier, which is welded on the shaft of rapping device. The inertial load $q(x)$, which appears on the lever of rapping device during the impact, is linearly distributed along the length of spring (Fig. 3) and it is in the function of a distance from the centre of rotation 0 . This loading causes the appearance of reactive force in the joint of lever and radial carrier, which is welded on the shaft of rapping device. Because of that, the mass of hammer will not be taken in consideration in the calculation, and the Eqs. (25) and (26) result in

$p_{\mathrm{u}}^{(1)}=p_{\mathrm{p}}^{(1)}$

$p_{\mathrm{u}}^{(2)}=p_{\mathrm{p}}^{(2)}$.

The mass of rapping device lever is $m$ and the length $l$, and it is released from the position A in a free fall till the position $\mathrm{A}^{\prime}$, where it collides with the mandrel, i.e. with the lower chamber of harp. The rapping device lever is connected by an elbow joint with the radial carrier, and it reciprocates. During the impact, the mean force of impact $N_{1}$ appears in the point $\mathrm{A}^{\prime}$, and in the point $\mathrm{A}$, the mean force of impact (reactive force) $N_{2}$. The velocity of differential mass of lever before the impact is $v(x)$, and after the impact, it is $c(x)$. The angular velocity of lever before the impact is $\omega$, and after the impact, it is $\Omega$. The differential mass at the distance $x$ before the impact will have the momentum $\mathrm{d} p_{\mathrm{u}}{ }^{(1)}$, and after the impact $\mathrm{d} p_{\mathrm{u}}{ }^{(2)}$. If the duration of impact is $\Delta t$, then the force impulse which acts on the lever of rapping device during the impact is equal to

$$
I=p_{\mathrm{u}}^{(2)}-p_{\mathrm{u}}^{(1)}=-\left(N_{1}+N_{2}\right) \cdot \Delta t
$$

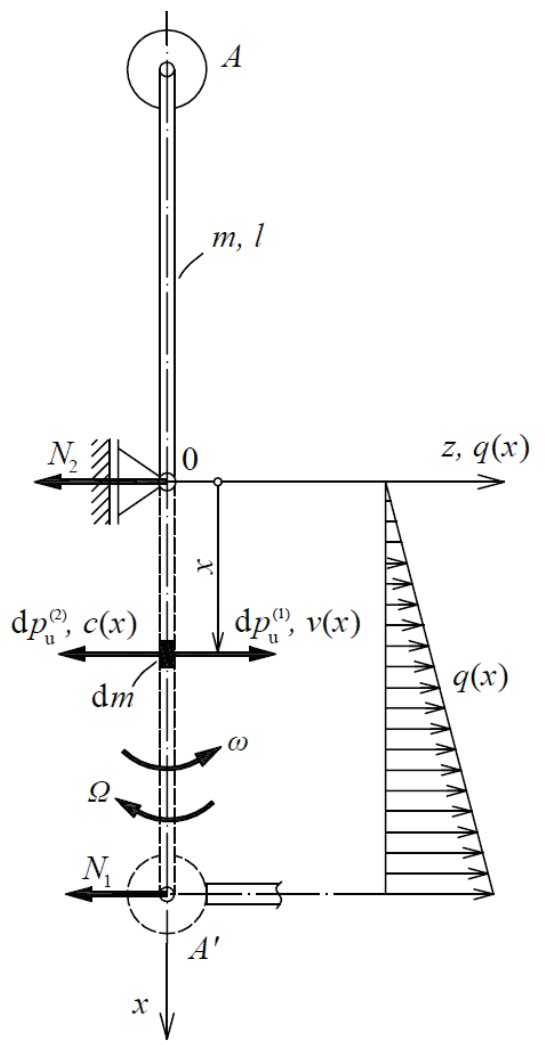

Figure 3 Kinetic model of impact of rapping device lever and mandrel/chamber of exchanger harp
If it is taken that the inertial load $q(x)$ during the impact is linear, then the relationship between the mean forces of impact $N_{1}$ and $N_{2}$, which appear because of the inertia of lever of rapping device, is equal to

$N_{1}=2 \cdot N_{2}$

The momentum of differential mass of lever $\mathrm{d} m$ just before the impact is

$\mathrm{d} p_{\mathrm{u}}^{(1)}=v(x) \cdot \mathrm{d} m$

then the momentum of lever of rapping device just before the impact is

$p_{\mathrm{u}}^{(1)}=\int_{m} v(x) \mathrm{d} m$

If $\omega$ is the angular velocity of lever just before the impact, then

$v(x)=\omega \cdot x$,

i.e.

$p_{\mathrm{u}}^{(1)}=\omega \cdot \int_{m} x \mathrm{~d} m$

Considering

$\mathrm{d} m=\rho \cdot \mathrm{d} V=\rho \cdot A \cdot \mathrm{d} x$,

thus

$p_{\mathrm{u}}^{(1)}=\omega \cdot \rho \cdot A \cdot \int_{0}^{l} x \mathrm{~d} x=\frac{1}{2} \cdot \omega \cdot \rho \cdot A \cdot l^{2}$.

The mass of rapping device lever can be written as

$m=\rho \cdot A \cdot l$,

so the Eq. (36) gets the definitive form

$p_{\mathrm{u}}^{(1)}=\frac{1}{2} \cdot \omega \cdot m \cdot l$.

According to the same analogy, it is possible to derive the expression for the momentum of rapping device lever just after the impact

$p_{\mathrm{u}}^{(2)}=-\frac{1}{2} \cdot \Omega \cdot m \cdot l$

If the Eqs. (30), (38) and (39) are inserted in (29), we get

$\frac{1}{2} \cdot m \cdot l \cdot(\Omega+\omega)=3 \cdot N_{2} \cdot \Delta t$ 
The factor of restitution $\mathrm{k}$ of the impact between two steel bodies, is known as a constant which connects the body velocities before and after the impact

$$
k=\frac{v_{0}(l)+\Omega \cdot l}{\omega \cdot l} .
$$

The Balance of momentum of body (24), applying the Eqs. (23), (38) and (39), can be written now as

$$
\frac{1}{2} \cdot \omega \cdot m \cdot l=-\frac{1}{2} \cdot \Omega \cdot m \cdot l+\left(m_{\mathrm{k}}+\frac{1}{2} \cdot m_{1} \cdot \mathrm{n}\right) \cdot v_{0}(l) .
$$

Let the mass of hammer be $m_{2}$. The law of conservation of mechanical energy for the motion of rapping device from the position A to the position $\mathrm{A}^{\prime}$ can be written as

$$
m \cdot g \cdot l+2 \cdot m_{2} \cdot g \cdot l=\frac{J \cdot \omega^{2}}{2}+\frac{m_{2} \cdot v^{2}}{2}
$$

Where $J$ is the dynamic momentum of inertia of rapping device lever, $\omega$ is the angular velocity of rapping device lever just before the impact, and $v$ is the velocity of rapping device hammer just before the impact with the mandrel. The velocity of hammer can be expressed by the angular velocity

$v=\omega \cdot l$.

The dynamic momentum of inertia of rapping device lever can be approximately calculated using the following expression

$$
J=\frac{m \cdot l^{2}}{3}
$$

By inserting the Eqs.(44) and (45) in the Eq. (43), we can get the expression for the angular velocity of rapping device lever just before the impact

$$
\begin{aligned}
& 2 \cdot g \cdot\left(m+2 \cdot m_{2}\right)=l \cdot \omega^{2} \cdot\left(\frac{m}{3}+m_{2}\right), \\
& \omega=\sqrt{\frac{2 \cdot g \cdot\left(m+2 \cdot m_{2}\right)}{l \cdot\left(\frac{m}{3}+m_{2}\right)}} .
\end{aligned}
$$

Applying the Eqs. (41) and (42), we can get the connection between the angular velocity of lever $\Omega$ after the impact and the angular velocity $\omega$ before the impact

$$
\begin{aligned}
& v_{0}(l)=k \cdot \omega \cdot l-\Omega \cdot l, \\
& \frac{1}{2} \cdot \omega \cdot m \cdot l=-\frac{1}{2} \cdot \Omega \cdot m \cdot l+\left(m_{\mathrm{k}}+\frac{1}{2} \cdot m_{1} \cdot \mathrm{n}\right) \cdot(k \cdot \omega \cdot l-\Omega \cdot l), \\
& \omega \cdot\left(\left(2 \cdot m_{\mathrm{k}}+m_{1} \cdot \mathrm{n}\right) \cdot k-m\right)=\Omega \cdot\left(m+\left(2 \cdot m_{\mathrm{k}}+m_{1} \cdot \mathrm{n}\right)\right), \\
& \Omega=\omega \cdot \frac{\left(2 \cdot m_{\mathrm{k}}+m_{1} \cdot \mathrm{n}\right) \cdot k-m}{m+\left(2 \cdot m_{\mathrm{k}}+m_{1} \cdot \mathrm{n}\right)} .
\end{aligned}
$$

Since the mass of lever $m$ is by far smaller than the mass of exchanger harp, the Eq. (47) can be written as

$$
\Omega \approx \omega \cdot \mathrm{k} .
$$

Considering the Eq. (48), from the Eq. (40) we can derive the mean force of impact

$$
N_{2}=\frac{m \cdot l \cdot \omega \cdot(\mathrm{k}+1)}{6 \cdot \Delta t} .
$$

\section{Numerical example:}

The given data are: $m_{2}=9 \mathrm{~kg}, \quad m=4 \mathrm{~kg}$ and $l=0,35 \mathrm{~m}$. The restitution factor for the case of steel body to steel body impact is: $k=0,5 \div 0,8$. The duration of impact is $\Delta t=0,001 \div 0,0001 \mathrm{~s}$.

Considering that the restitution factor and the duration of impact are the values that are determined by measuring, the data presented above are given in the limits which can be found in the reference books [12].

The angular velocity of rapping device lever just before the impact is

$$
\omega=\sqrt{\frac{2 \cdot g \cdot\left(m+2 \cdot m_{2}\right)}{l \cdot\left(\frac{m}{3}+m_{2}\right)}}=10,925 \mathrm{rad} / \mathrm{s}
$$

a) The largest force of the impact $N_{2}$ will be calculated for:

$$
\begin{aligned}
& k=0,8, \Delta t=0,001 \div 0,0001 \mathrm{~s}, \\
& N_{2}=\frac{m \cdot l \cdot \omega \cdot(\mathrm{k}+1)}{6 \cdot \Delta t}=45885 \mathrm{~N}
\end{aligned}
$$

b) The smallest force of impact $N_{2}$ will be calculated for:

$$
\begin{aligned}
& k=0,5, \Delta t=0,001 \mathrm{~s}, \\
& N_{2}=\frac{m \cdot l \cdot \omega \cdot(k+1)}{6 \cdot \Delta t}=3824 \mathrm{~N} .
\end{aligned}
$$

c) The impact force $N_{2}$ for the mean value of duration and the mean value of restitution factor:

$$
\begin{aligned}
& k=0,65, \Delta t=0,00055 \mathrm{~s}, \\
& N_{2}=\frac{m \cdot l \cdot \omega \cdot(k+1)}{6 \cdot \Delta t}=7647,5 \mathrm{~N} .
\end{aligned}
$$

\section{Determination of influence of inertial forces during the impact of rapping device in the case when the harp is blocked on the carriage guide}

If the harp is blocked on the carriage guide during the impact of rapping device, it will not take any kinetic energy. In that case, the Eq. (41) applies for the restitution factor, where the velocity $v_{0}(l)$ will be equal to zero

$$
k=\frac{\Omega \cdot l}{\omega \cdot l} .
$$


From this we get

$\Omega=\omega \cdot k$,

i.e. the blocked harp will not significantly influence the rapping device lever angular velocity after the impact. Because of that, there will be no significant change in the mean force of $\mathrm{N}_{2}$

\section{Nominal stress calculation on the critical welded joint}

After the calculation of mean impact force $N_{2}$, according to the Fig. 5, the bending moment of welded joint $M_{\mathrm{b}}$ can be calculated. The double fillet weld with a characteristic dimension $a$ was used, according to Fig. 4.

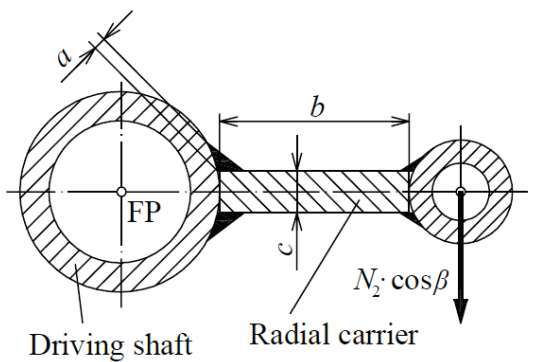

Figure 4 Welded joint of drive shaft and radial carrier

The bending moment of welded joint is

$$
M_{\mathrm{b}}=N_{2} \cdot b \cdot \cos \beta .
$$

The angle $\beta$ is shown in Fig. 5. The nominal stress due to the bending of welded joint can be calculated using the expression

$$
S_{\mathrm{b}}=\frac{M_{\mathrm{b}}}{W},
$$

where the section modulus of the welded joint cross section is

$$
\begin{aligned}
& W=\frac{2 \cdot I}{c+2 \cdot a}, \\
& I=2 \cdot\left(\frac{d \cdot a^{3}}{12}+d \cdot a \cdot \frac{c^{2}}{4}\right),
\end{aligned}
$$

where $d$ is the width of radial carrier. The normal nominal stress in the welded joint is

$S_{N}=\frac{N_{2} \cdot \sin \beta}{A}$,

where the surface of weld is

$$
A=2 \cdot a \cdot d \text {. }
$$

The total nominal stress in the critical welded joint is

$$
S=S_{\mathrm{b}}+S_{N}
$$

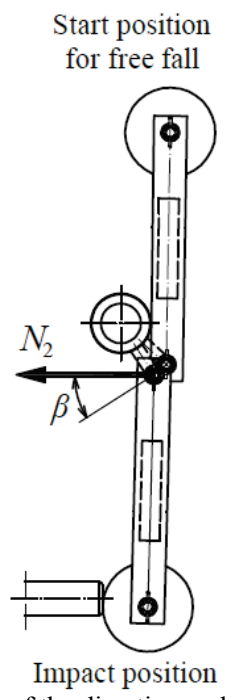

Figure 5 Representation of the direction and grips of impact forces $N_{2}$

\section{Numerical example:}

In the calculation, the impact of hammer and mandrel will be taken into account, when the impact axis is parallel with the longitudinal axis of mandrel, then $\beta=32,42^{\circ}$. The given data are: $b=48 \mathrm{~mm}, c=20 \mathrm{~mm}, a=5 \mathrm{~mm}$ and $d=60 \mathrm{~mm}$.

a) The nominal stress calculation for the maximum possible force of impact: $N_{2}=45885 \mathrm{~N}, A=600 \mathrm{~mm}^{2}$, $I=61250 \mathrm{~mm}^{4}, W=4083 \mathrm{~mm}^{3}, M_{\mathrm{b}}=1859203 \mathrm{~N} \cdot \mathrm{mm}$, $S_{\mathrm{b}}=455 \mathrm{MPa}, S_{N}=41 \mathrm{MPa}, S=496 \mathrm{MPa}$.

b) The nominal stress calculation for the minimum possible force of impact: $N_{2}=3824 \mathrm{~N}$, $M_{\mathrm{b}}=154944 \mathrm{~N} \cdot \mathrm{mm}, \quad S_{\mathrm{b}}=40 \mathrm{MPa}, \quad S_{N}=4 \mathrm{MPa}$, $S=44 \mathrm{MPa}$.

c) The nominal stress calculation for the impact force $\mathrm{N}_{2}$ when the mean duration values of the impact and restitution factor are taken: $N_{2}=7647,5 \mathrm{~N}$, $M_{\mathrm{b}}=309867 \mathrm{~N} \cdot \mathrm{mm}, \quad S_{\mathrm{b}}=76 \mathrm{MPa}, \quad S_{N}=7 \mathrm{MPa}$, $S=83 \mathrm{MPa}$

\section{Fatigue calculation in the critical welded joint}

The material of radial carrier is S235JRG2, and the material of drive shaft is S355J2G3. According to FKM [13], the fatigue limit value for the completely reversed nominal stress $\left(R_{\mathrm{zd}}=-1\right)$ of welded joints of structural steel is $\sigma_{\mathrm{w}}=92 \mathrm{MPa}$, and it does not depend on the type of structural steel. Since the welded joint is loaded with the alternating loading, it will be necessary to take the mean nominal stress into consideration. The amplitude nominal stress can be calculated from the expression

$S_{\mathrm{a}}=\frac{S}{2}$.

The mean nominal stress is equal to the amplitude nominal stress 


$$
S_{\mathrm{m}}=\frac{S}{2} \text {. }
$$

The criterion of permanent fatigue limit of welded joint of radial carrier and drive shaft of rapping device is

$$
S_{\mathrm{a}}<S_{\mathrm{AK}},
$$

where $S_{\mathrm{AK}}$ is the fatigue limit for the nominal stress which can be calculated according to the expression

$$
S_{\mathrm{AK}}=K_{\mathrm{AK}} \cdot K_{\mathrm{E}, \sigma} \cdot S_{\mathrm{WK}} \cdot
$$

The fatigue limit for the completely reversed nominal stress can be calculated according to the expression

$$
S_{\mathrm{WK}}=\frac{\sigma_{\mathrm{W}}}{\mathrm{K}_{\mathrm{WK}}} .
$$

where $K_{\mathrm{WK}}$ is the design factor for the nominal stress and it is equal to

$$
K_{\mathrm{WK}}=\frac{225}{F A T} \text {. }
$$

The fatigue class for the assessment with nominal stress for the T-joint with the fillet weld of radial carrier and drive shaft of rapping device is $F A T=45$ [14]. Therefore, the design factor for the nominal stress has the value of $K_{\mathrm{WK}}=5$. According to the expression (63), the fatigue limit for the completely reversed nominal stress is $S_{\mathrm{WK}}=18,4 \mathrm{MPa}$. The mean stress factor $K_{\mathrm{AK}}$ depends on the type of preloading and the field of mean stress. Since in this case, the stress ratio $R$ is constant at all time, according to FKM [13] the type of preloading is F2. Since the alternating loading is tensile, $R=0$, FIELD II of mean stress is valid. For the type of preloading F2 and FIELD II of mean stress, the expression for calculating the mean stress factor is

$$
K_{\mathrm{AK}}=\frac{1}{1+M_{\sigma} \cdot \frac{S_{\mathrm{m}}}{S_{\mathrm{a}}}} .
$$

where $M_{\sigma}$ is the mean stress sensitivity. The mean stress sensitivity with the welded components depends on the intensity of residual stress, and not on the tensile strength of base material. For the high residual stress, it is valid that $M_{\sigma}=0$. High residual stresses are to be assumed in the case of welding without the measures for reducing the residual stress, which is the case here. Since $M_{\sigma}=0$, it follows that $K_{\mathrm{AK}}=1$. The factor of residual stress is $K_{\mathrm{E}, \sigma}=1$, since there are high residual stresses present in the welded joint [13]. According to the Eq. (62), it follows that $S_{\mathrm{AK}}=S_{\mathrm{WK}}=18,4 \mathrm{MPa}$.

According to EN10025, for the thickness 3 to 100 $\mathrm{mm}$ and S235JRG2, the minimum tensile strength at the room temperature is $R_{\mathrm{m}}=360 \mathrm{MPa}$. The static strength of welded joint can be calculated according to the expression

$S_{\mathrm{SK}}=R_{\mathrm{m}} \cdot \alpha_{\mathrm{W}}$,

where $\alpha_{\mathrm{W}}$ is the weld factor which has the value of $\alpha_{\mathrm{W}}=0,8[13]$ for the double fillet weld and compressive/tensile stress. According to the expression (66), the static strength of welded joint has the value of $S_{\mathrm{SK}}=288 \mathrm{MPa}$.

The maximum number of loading cycles till the crack appears can be approximately determined with the linearization of Wöhler's curve in the low-cycle fatigue area

$n_{\mathrm{c}}=\frac{S_{\mathrm{SK}}-S_{\mathrm{a}}}{S_{\mathrm{SK}}-S_{\mathrm{AK}}} \cdot n_{0}$,

during which the limited number of cycles is adopted $n_{0}=10^{6}$.

\section{Numerical example:}

a) The testing of fatigue strength of welded joint for the highest possible nominal stress during the impact of rapping device: $S=496 \mathrm{MPa} . \quad S>S_{\mathrm{SK}} \rightarrow$ The weld cannot endure even one impact of the rapping device.

b) The testing of fatigue strength of welded joint for the lowest possible nominal stress during the impact of rapping device: $S=44 \mathrm{MPa}, S_{\mathrm{a}}=22 \mathrm{MPa} . S_{\mathrm{a}}>S_{\mathrm{AK}} \rightarrow$ The amplitude stress is $3,6 \mathrm{MPa}$ higher than the fatigue limit for nominal stress. The welded joint cannot endure the infinite number of impacts of the rapping device.

c) Determining the number of loading cycles that will cause the beginning of fatigue crack, taking into account the mean value of impact duration and the factor of restitution: $S=83 \mathrm{MPa}, S_{\mathrm{a}}=41,5 \mathrm{MPa}$.

Applying the expression (67), we can get the information that the crack appears at $n_{c}=914317$ loading cycles. According to the manufacturer's guaranty, the rapping device can work for two years. The allowed number of impacts per day, according to the recommendations of manufacturers, is 48 . Therefore, it is possible to calculate that the guarantied number of impacts of rapping device is $n_{\mathrm{g}}=35040$. Since $n_{\mathrm{c}}<n_{\mathrm{g}}$, it can be said that the rapping devices should have worked for the guarantied time period. This was not the case in practice.

\section{Conclusion}

The paper proposes an analytical model of strength calculation of welded joint of drive shaft and radial carrier of rapping device for the garbage incineration boiler, which is exposed to the fatigue loading. Applying this model of calculation, the strength calculations of welded joint have been made for the real example of rapping device.

The conducted fatigue calculations of welded joint are approximate and can be used as a reference at the 
fatigue strength evaluation of critical welded joint. The reason for this is the use of empirical values for the impact duration and restitution factor, which are given in the data range. The possible initial damage, such as the micro-cracks, is not taken into consideration in this calculation.

Taking that the factor of restitution has the highest value possible, and that the collision duration is as short as possible, it follows that the appearance of cracks in the welded joint should come right at the first impact of rapping device.

The calculations of fatigue strength of welded joint of radial carrier and drive shaft of rapping device have generally showed that the welded joint cannot permanently withstand the dynamic loads appearing because of the rapping device.

If the mean value is applied to the data of duration of impact and the restitution factor as the reliable statistics, then as a result of calculations, we get that the welded joint can withstand the guarantied number of loading cycles (i.e. the number of rapping device impacts).

From these considerations, it can be concluded with high probability that the welded joint of radial carrier and drive shaft is sufficiently dimensioned to withstand a guaranteed work period of the rapping device.

The reason for the crack in the welded joint should be looked for in the poor microstructure of the welded joint and possible existing micro-cracks. The low toughness of the welded joint and the existence of micro-cracks or stress concentrations, at the dynamic impact loading allows a very rapid propagation of cracks with the final fracture. With the existence of initial micro-cracks, and based on the analysis above, the outcome of fracture in the welded joint can be taken as safe, even within the guaranteed number of cycles (impacts). This is difficult to prove if there are no images of the microstructure and the measured hardness for the said welded joints. These measurements will be carried out in further research.

The reduction of stress on the critical welded joints can be achieved by increasing the bearing surface of welded joint and by decreasing the lever mass of rapping device.

The structure of welded joint can be improved by subsequent heat treatment. With the structural components loaded by the impact loading, the highest possible toughness is desirable.

In addition to the required safety factor (the proposal $S=1,5$ ), the maximum value of factor of restitution and the minimum duration of collision, the proposed analytical model of calculation provides a good basis for the dimensioning of welded joint of radial carrier and drive shaft of rapping device. It would be necessary to apply the double fillet weld (K-preparation of the welded joint).

The proposed mathematical model of calculation can give more accurate results, if the exact duration of the impact and the exact amount of restitution factor can be determined by measuring. If the welded joint must be made as the double fillet weld, it would be required to apply the criteria of fracture mechanics for the dimensioning of such welded joint.

Due to the impact of rapping device, the harp of heat exchanger should be swung to cause the separation of layers of ash. Sometimes it happens that the harp is blocked in its guides, and free swinging cannot occur. In this paper, it has been analytically proved that the blocked harp does not affect the occurrence of fracture of the welded joint of radial carrier and drive shaft

\section{References}

[1] Irvine, H. M. Structural Dynamics for the Practising Engineer. Allen and Unwin, London, 1986. DOI: 10.4324/9780203473610

[2] Harris, C. M.; Crede, C. E. Shock and Vibration Handbook. McGraw-Hill, New York, 1976.

[3] Damjanović, D.; Kozak, D.; Sertić, J.; Gelo, I.; Konjatić, P.; Novoselac, S. Udarno opterećenje harfe izmjenjivača topline (Impact Load of the Superheater Harp). // The fifth Congress of Croatian Society of Mechanics /DonjaStubica, 2013.

[4] Sertić, J.; Krpan, A.; Damjanović, D.; Gelo, I. Udarno opterećenje harfe izmjenjivača topline na kotlu Vaasa, 26.0183 (Impact Load of the Superheater Harp of the Vaasa Boiler). Boiler project 26.0183 of ĐĐ TEP d.o.o., Technical report, Mechanical Engineering Faculty in SlavonskiBrod, 2012.

[5] Johnson, A. A.; Storey, R. J. The impact fatigue properties of iron and steel. // Journal of Sound and Vibration. 308, (2007), pp. 458-466. DOI: 10.1016/j.jsv.2007.06.044

[6] Shul'ginov, B. S. Fatigue strength of steels under multicycle impact loading. // Strength of Materials. 26, 3(1994). DOI: 10.1007/BF02209402

[7] Davidenkov, N. N.; Belyaeva, E. I. Examination of impact fatigue. // Metalloved. Obrab. Met. 11, (1956), pp. 4-10.

[8] Silkin, E. A. Impact-Cyclic Strength of Steels Used in Agricultural Engineering (in Russian). Mashinostroenie, Moscow, 1964

[9] Tolkachnik, S. V. Impact Fatigue under Stress Concentration Conditions. // Otd. Tekh. Nauk, Izv. Akad. Nauk SSSR. 5, (1958), pp. 106-110.

[10] Sidnev, V. I. Examination of the relationships governing fatigue failure of structural steels under impact loading. Dissertation for the Degree of the Candidate of Technical Sciences, Kiev, 1967.

[11] Sertić, J.; Gelo, I.; Bučević-Keran, D. Weld Joint Strength Analysis of Radial Carrier and Drive Shaft Strength Analysis of the Rapping Devices - Steam boiler Riverside. Technical report, Revision 1, ĐĐ TEP d.o.o., Mechanical Engineering Faculty in SlavonskiBrod, 2014.

[12] Matejiček, F. Kinetika sa zbirkom zadataka. Strojarski fakultet u Slavonskom Brodu, Slavonski Brod, 2010.

[13] FKM-Analytical Strength Assessment. 5th ed. VDMA Verlag, Germany, 2003.

[14] Hobbacher, A. Fatigue Design of Welded Joints and Components. Recommendations of the Joint Working Group XIII-XV, XIII-1539-96 / XV-845-96. Abbington Publishing, Abbington Hall, Abbington, Cambridge CB1 6AH, England, 1996. DOI: 10.1533/9780857093189

\section{Authors' addresses}

Josip Sertić, Mech. Eng.

Prof. Ivan Samardžić, PhD

Prof. Dražan Kozak, PhD

Ivan Gelo, Mag. Ing. Mech.

Mechanical Engineering Faculty in Slavonski Brod,

Josip Juraj Strossmayer University of Osijek,

Trg I. B. Mažuranić 2, HR-35000 Slavonski Brod,

Republic of Croatia

E-mail: josip.sertic@sfsb.hr

E-mail: ivan.samardzic@sfsb.hr 
E-mail: drazan.kozak@sfsb.hr

E-mail: ivan.gelo@sfsb.hr

\section{Damir Šimunić, Mech. Eng.}

Đuro Đaković Termoenergetska postrojenja d.o.o.,

Member of OJSC Power Machines Russia,

Mile Budaka 1, HR-35000 Slavonski Brod,

Republic of Croatia

E-mail: damir.simunic@ddtep.power-m.hr

Dino Bučević-Keran, Mag. Ing. Mech.

Đuro Đaković Specijalna vozila d.d.

Mile Budaka 1, HR-35000 Slavonski Brod,

Republic of Croatia

E-mail: dino.bucevic@ddsbv.hr 